\title{
Studies on Liver and Muscle Phosphorylases
}

\author{
II. Effects of Diet
}

Takeshi ITO

2nd Department of Internal Medicine, Gifu University School of Medicine, Gifu, Japan

(Director : Professor S. Hayase)

In the previous paper, alternations of glycogen metabolism under various hormonal conditions were studied by the measurement of liver and muscle phosphorylase activities, and an evidence suggested that various hormones showed the direct and indirect effects on this enzyme activity. In this report the effects of fasting and feeding on a high carbohydrate or high lipid diet upon the phosphorylase activity are described and the mechanism producing the apparent changes are also discussed.

\section{Materials and Methods}

Phosphorylase activity and glycogen content were determined as described in the preceding paper. Fasting was continued for 72 hours with the normal rats and at intervals each entity was determined. Experimental diet which contained a high proportion of carbohydrate or lipid was given for 2 weeks to the normal or alloxan diabetic animals ( 1 week after a single intramuscular injection of $30 \mathrm{mg}$. of alloxan monohydrate).

\section{Results and Discussions}

(1) Fasting for 12 hours caused a marked decrease in the liver glycogen content. Liver phosphorylase activity increased up to 12 hours of fasting and then decreased. In muscle, phosphorylase activity as well as glycogen content was gradually decreased during fasting for 72 hours. (2) A high carbohydrate diet increased liver phosphorylase activity in the normal rats. It caused, however, no change in alloxan diabetic animals, implying that insulin might be concerned with the alterations observed in the normal rats. (3) Normal animals fed on a high lipid diet showed a decrease in liver glycogen. Phosphorylase activity was increased in liver, but decreased in muscle. Alloxan diabetic rats fed on the same diet had a remarkably low phosphorylase activity in liver. This fact suggests the participation of insulin in the glycogen controling system.

Based on the results described above, dynamic aspects of glycogen metabolism and thier modifications under such various feeding conditions as fasting, high carbohydrate or high lipid diets were discussed.

(See pp. 236 240) 


\title{
肝, 筋 Phosphorylase 亿関する研究
}

\author{
（II）食 飭 の 影 響
}

岐阜大学医学部第二内科（担当：早瀬正二教授）

伊東毅

（昭和44年 1 月13日受付）

.肝, 筋 phosphorylase 活性を絶食動物, 高糖食飼育動物, 高脂肪食飼育動物において測定し, その 変動を観察すると共に糖原量を合せて測定し, 本酵素活性の変動の意義および機序について論じた，絶 食は早期に phosphorylase 活性の上昇を示し糖原分解の促進が考えられ, 又高糖食は肝 phosphorylase 活性の上昇, 糖原量の不変を示し, 糖原合成, 分解の促進を思わしめた。 高脂肪食では phosphorylase 活性の上昇がみられた。 それらの変動は insulin, glucagon の介在が反映しているものと考えられた.

\section{緒言}

前報1においては著者はホルモン環境変動下の糖原系の動きを肝, 筋 phosphorylase 活性の変動を中心と し種々ホルモンの本酵素に及ぼす直接, 間接作用について論じてきたが近年食慨組成にもとずく糖代謝異常 も多く報告され ${ }^{233) 42}$ ，二次的なホルモン作用が問題となつている。本報においては絶食動物の肝，筋につ いて phosphorylase 活性を測定するとともに糖原量, 血糖値を測定し糖原系の動きを絶食後経時的に観察 し, さらに正常動物, 実験的糖尿病動物について高糖質食飼育, 高脂肪食飼育の影響を同様に観察した。

\section{対象および方法}

実験動物はすべてオリエンタル固型飼料（G E- II）で飼育した $200 \mathrm{~g}$ 前後のウィスター系雄性ラットを使 用し絶食の影響は 6 時間，12時間，24時間，48時間，72時間絶食した 1 グループ 5 匹のラットを使用した。 実験的糖尿病動物は alloxan monohydrate 30mg. 1 回筋注後 1 週間目に尿糖陽性なものを用いた。使用し た実験食は Table 1 亿示す如く蛋白質量をほぼ一定とした脂肪，糖質に変化をあたえた，摄取カロリーは ほぼ一定になる条件で正常ラット，alloxan 糖尿病ラットにそれぞれの実験食で 2 週間飼育し実験に使用し た.

Table 1. Constitution of experimental diets

\begin{tabular}{l|c|c|c}
\hline & control & high fat & high carbohydrate \\
\hline \hline carbohydrate & 56 & 50 & 70 \\
protein & 24 & 20 & 20 \\
fat & 5 & 20 & 5 \\
cellulose & 4.5 & 2 & 3 \\
mineral & 4 & 5 & 2 \\
vitamin powder & 2 & 3 & \\
\hline
\end{tabular}


実験動物は $10^{\circ} \mathrm{C}$ 室温でエーテル酔麻下で断頭し， すみやかに血糖測定するとともに出来るだけ放血し， 肝, 筋を取り出し, 前報 ${ }^{1)}$ と同じ方法により phosphorylase 活性, 糖原含有量, 血糖值を測定した. 測定值についてはphosphorylase活性は $\Delta \mathrm{D} / \mathrm{min} / \mathrm{gm}$. wet. w., $\Delta \mathrm{D} / \mathrm{min} /$ total liver wet. w. 糖原量は $\mathrm{mg} /$ $\mathrm{gm}$, 血糖値はmg/diの単位で表わした.

\section{成}

\section{績}

（1）絶食実験 :

Fig. (1)上段に示す如く肝重量は12時間，24時間と 減少し, 24 時間では約 $1 / 3$ と低下した. 肝糖原量も 12 時間までに急速な低下を示した．肝 phosphorylase 活性は 6 時間で約 2 倍，12時間で 3 倍と上昇し，そ の後時間の経過とともに下降した。 筋においては Fig. (1)下段に示し如く糖原含有量, phosphorylase 活性とも著変を示さないが48時間，72時間では低下 の態度を示した.

(2) 高糖食飼育実験（Table 2)

i ）正常ラット：それぞれ対照に比し血糖值は上 昇傾向を示し, 肝では糖原量は不変, phosphorylase 活性は有意の上昇，筋では糖原量は有意の上昇， phosphorylase 活性は不変の成績を得た。

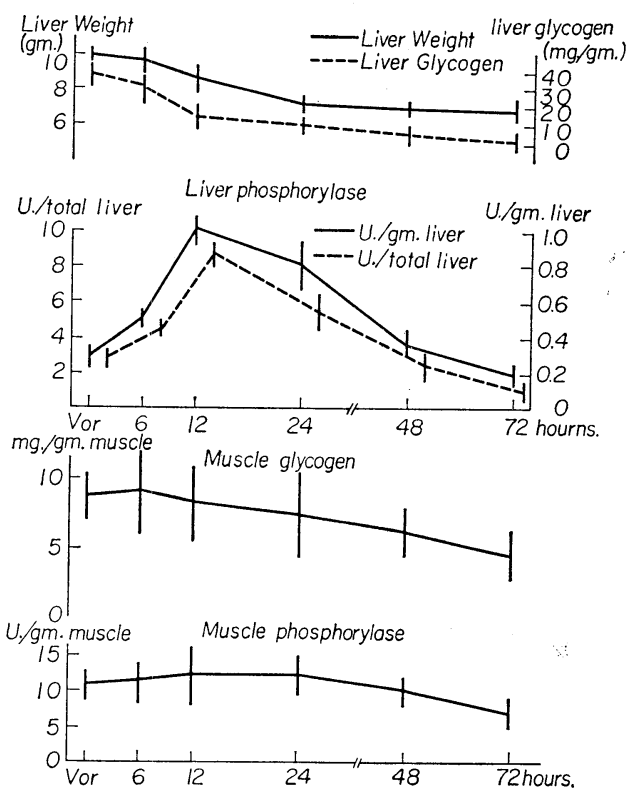

Fig. 1. Effect of starvation on liver weight, and on glycogen content ond phsphorylase activity of liver and muscle in normal rats.

*Each vertical line showmean and standard deviation of five rats.

ii ) alloxan 糖尿病ラット：血糖值は対照に比しさらに高值を示しており, 肝については糖原量は減少を

Table 2. Effect of high carbohydrate diet on body weight, liver weight, blood sugar, and on phosphorylase activity and glycogen content of liver and muscle in normal and alloxan diabetic rats.

\begin{tabular}{|c|c|c|c|c|c|c|c|c|}
\hline \multirow{3}{*}{ Experimental group } & \multirow{3}{*}{$\begin{array}{c}\text { Body } \\
\text { Wt. } \\
\text { (gm.) }\end{array}$} & \multirow{3}{*}{$\begin{array}{l}\text { Liver } \\
\text { Wt. } \\
\text { (gm.) }\end{array}$} & \multicolumn{2}{|c|}{ Glycogen } & \multicolumn{3}{|c|}{ Phosphorylas } & \multirow{3}{*}{$\begin{array}{c}\text { Blood } \\
\text { sugar } \\
(\mathrm{mg} / \mathrm{dl})\end{array}$} \\
\hline & & & Liver & Muscle & Liv & ver & Muscle & \\
\hline & & & \multicolumn{2}{|c|}{ (mg/gm.) } & $\begin{array}{c}\mathrm{U} . / \mathrm{gm} . \\
\text { liver }\end{array}$ & $\begin{array}{c}\text { U./total } \\
\text { liver }\end{array}$ & $\begin{array}{l}\mathrm{U} / \mathrm{gm} . \\
\text { muscle }\end{array}$ & \\
\hline Gontrol & $\begin{array}{r}295 \\
\pm 10 \\
\end{array}$ & $\begin{array}{l}10.6 \\
\pm 1.6 \\
\end{array}$ & $\begin{array}{l}37.0 \\
\pm 4.2 \\
\end{array}$ & $\begin{array}{r}7.5 \\
\pm 1.5 \\
\end{array}$ & $\begin{array}{c}0.29 \\
\pm 0.04 \\
\end{array}$ & \begin{tabular}{|c|}
3.40 \\
\pm 0.26 \\
\end{tabular} & $\begin{array}{r}13.2 \\
\pm 1.65 \\
\end{array}$ & $\begin{array}{r}120 \\
\pm 16 \\
\end{array}$ \\
\hline High carbohydrate diet & $\begin{array}{l}230^{*} \\
\pm 20\end{array}$ & $\begin{array}{r}7.8^{*} \\
\pm 0.9 \\
\end{array}$ & $\begin{array}{l}40.0 \\
\pm 4.6 \\
\end{array}$ & $\begin{array}{l}12.6^{* *} \\
\pm 2.6 \\
\end{array}$ & $\begin{array}{c}0.60^{* *} \\
\pm 0.05 \\
\end{array}$ & $\begin{array}{c}4.67^{* *} \\
\pm 0.18 \\
\end{array}$ & $\begin{array}{l}11.5 \\
\pm 1.08 \\
\end{array}$ & $\begin{array}{r}140 \\
\pm 12 \\
\end{array}$ \\
\hline Alloxan & \begin{tabular}{r|}
220 \\
\pm 14 \\
\end{tabular} & $\begin{array}{c}9.0 \\
\pm 1.3 \\
\end{array}$ & $\begin{array}{l}23.0 \\
\pm 3.5\end{array}$ & $\begin{array}{c}8.0 \\
\pm 1.8 \\
\end{array}$ & $\begin{array}{c}0.31 \\
\pm 0.11 \\
\end{array}$ & $\begin{array}{c}2.78 \\
\pm 0.72 \\
\end{array}$ & $\begin{array}{l}12.0 \\
\pm 1.25\end{array}$ & $\begin{array}{r}289 \\
\pm 36 \\
\end{array}$ \\
\hline $\begin{array}{l}\text { Alloxan }+ \text { High } \\
\text { carbohydrate diet }\end{array}$ & $\begin{array}{l}165^{* *} \\
\pm 16\end{array}$ & $\begin{array}{r}7.7^{*} \\
\pm 1.2\end{array}$ & $\begin{array}{l}15.0^{* *} \\
\pm 2.6\end{array}$ & $\begin{array}{c}6.0 \\
\pm 0.9\end{array}$ & $\begin{array}{c}0.32 \\
\pm 0.08 \\
\end{array}$ & $\begin{array}{c}2.47 \\
\pm 0.29 \\
\end{array}$ & $\begin{array}{l}10.5 \\
\pm 1.00 \\
\end{array}$ & $\begin{array}{l}410^{* *} \\
\pm 23 \\
\end{array}$ \\
\hline
\end{tabular}

Each group describes the average values of five rats. (Mean values \pm Standard deviation)

** Significantly different from control values $\mathrm{P}<0.01$

* Idem $\quad \mathrm{P}<0.05$

Control : control diet feeded normal rats. High cardohydrate diet : high carbhydrate diet feeded normal rats.

Alloxan : control diet feeded alloxan diabetic rats. Alloxan + High carbohydrate diet feeded alloxan diabetic rats. 
示した. phosphorylase 活性については有意の変動は認めない. 筋では対照に比し変化はみられない.

(3) 高脂肪飼育実験（Table 3)

i ）正常ラット：高脂肪食飼育の影響は血糖值の軽度上昇であつた. 肝では糖原量は対照に比し減少を示 し, phosphorylase 活性は対照に比し有意の上昇を示した。筋では糖原量は変化なく, phosphorylase 活性 は有意の低下を示した.

Table 3. Effect of high fat diet on body weight, liver weight, blood sugar, and on phosphorylase activity and on phosphorylase activity and glycogen contentof liver and muscle in normal and alloxan diabetic rats.

\begin{tabular}{|c|c|c|c|c|c|c|c|c|}
\hline \multirow{3}{*}{ Experimental group } & \multirow{3}{*}{$\begin{array}{l}\text { Body } \\
\text { Wt. } \\
\text { (gm.) }\end{array}$} & \multirow{3}{*}{$\begin{array}{l}\text { Liver } \\
\text { Wt. } \\
\text { (gm.) }\end{array}$} & \multicolumn{2}{|c|}{ Glycogen } & \multicolumn{3}{|c|}{ Phosphorylase } & \multirow{3}{*}{$\begin{array}{c}\text { Blood } \\
\text { sugar } \\
\text { (mg/dl.) }\end{array}$} \\
\hline & & & Liver & Muscle & $\mathrm{Li}$ & ver & Muscle & \\
\hline & & & \multicolumn{2}{|c|}{ (mg/gm.) } & $\begin{array}{c}\text { U./gm. } \\
\text { liver }\end{array}$ & $\begin{array}{c}\text { U./total } \\
\text { liver }\end{array}$ & $\begin{array}{l}\text { U./gm. } \\
\text { muscle }\end{array}$ & \\
\hline Control & $\begin{array}{r}295 \\
\pm 10 \\
\end{array}$ & $\begin{array}{l}10.2 \\
\pm 0.8\end{array}$ & $\begin{array}{l}45.0 \\
\pm 6.2\end{array}$ & $\begin{array}{c}5.2 \\
\pm 1.9 \\
\end{array}$ & $\begin{array}{c}0.26 \\
\pm 0.02 \\
\end{array}$ & $\begin{array}{c}2.65 \\
\pm 0.32 \\
\end{array}$ & $\begin{array}{c}15.5 \\
\pm 1.80 \\
\end{array}$ & $\begin{array}{r}116 \\
\pm 20\end{array}$ \\
\hline High fat diet & $\begin{array}{r}310 \\
\pm 20 \\
\end{array}$ & $\begin{array}{l}11.3 \\
\pm 1.2 \\
\end{array}$ & $\begin{array}{r}30.2^{*} \\
\pm 7.6 \\
\end{array}$ & $\begin{array}{c}6.4 \\
\pm 1.8 \\
\end{array}$ & $\begin{array}{c}0.37^{* *} \\
\pm 0.02 \\
\end{array}$ & $\begin{array}{r}3.20^{*} \\
\pm 0.28 \\
\end{array}$ & $\begin{array}{r}11.2^{*} \\
\pm 1.03 \\
\end{array}$ & $\begin{array}{r}135 \\
\pm 18 \\
\end{array}$ \\
\hline Alloxan & $\begin{array}{r}225 \\
\pm 26\end{array}$ & $\begin{array}{c}9.2 \\
\pm 1.6\end{array}$ & $\begin{array}{l}15.0 \\
\pm 3.8\end{array}$ & $\begin{array}{c}4.6 \\
\pm 1.3\end{array}$ & $\begin{array}{c}0.23 \\
\pm 0.08\end{array}$ & $\begin{array}{c}2.12 \\
\pm 0.19\end{array}$ & $\begin{array}{c}11.8 \\
\pm 2.08\end{array}$ & $\begin{array}{r}207 \\
\pm 10\end{array}$ \\
\hline Alloxan + High fat diet & $\begin{array}{r}240 \\
\pm 32 \\
\end{array}$ & $\begin{array}{l}10.8 \\
\pm 0.7 \\
\end{array}$ & $\begin{array}{l}19.0 \\
\pm 2.4\end{array}$ & $\begin{array}{c}3.8 \\
\pm 0.8\end{array}$ & $\begin{array}{c}0.08^{* *} \\
\pm 0.03\end{array}$ & $\begin{array}{c}0.87^{* *} \\
\pm 0.24\end{array}$ & $\begin{array}{c}9.82 \\
\pm 1.60\end{array}$ & $\begin{array}{l}290^{* * *} \\
\pm 40\end{array}$ \\
\hline
\end{tabular}

Each group describes the average values of five rats. (Mean values \pm Standard deviation)

** Significantly different from control values $\mathrm{P}<0.01$

* Idem $\quad \mathrm{P}<0.05$

Control : control diet feeded normal rats. High fat diet : high fat diet feeded normal rats.

Alloxan : control diet feeded alloxan diabetic rats. Alloxan + High fat diet $:$ high fat diet feeded alloxan diabetic rats.

ii ）alloxan 糖尿病ラット：高脂肪食飼の成績は血糖伹については対照に比して上昇を示した。肝におい ては糖原量は不変, phosphorylase 活性は対照に比して有意の低下を示した。筋糖原量, 筋 phosphorylase 活性はそれぞれ対照にくらべ有意の変化は示さなかった。

phosphorylase 活性は食餌の影響をうけて活潑に反応し, 特に肝においては反応著明であり, 糖原系の調 節に大きく関与しているものと思われる，著者”はすでに本醉素活性のホルモン支配について述べてたが， 以下は本酵素活性の変動を中心に, 糖原量の成績を綜合し, 糖原素の動きを類推し, Phosphorylase 活性変 動の意義およびその機序について各食慨条件に考慮を加えた。

( I ） 絶食の影響について

絶食による肝醉素活性の変動についてはてれまでの報告をみると肝 G-6-Pase ${ }^{5 / 6)}$ phosphoglucoisomelase

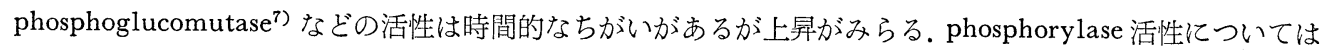
低下あるいは上昇と報告されている778). 本研究についてみると Fig. (1)にみられるように絶食後12時間迄に 肝重量, 肝糖原量のあきらかな低下をみとめ, これに対し肝 phosphorylase 活性の著明に上昇し12時間で 約 3 倍の活性上昇がみられる. 絶食後12時間で糖原は著明に減少, 殆んぞ固渴し以後その值を持続する. 故 にての絶食12時間以後は糖原に依存して血糖を維持するとは考えられず，糖新生に依存するものと推論され る.

\section{（II） 高糖質食飼育の影響}

正常動物を高糖質食で飼育すると, Table 2 の加く肝 phosphorylase 活性の著明な上昇をみとめ肝糖原 分解の促進が考えられる。しかし肝糖原量は不変であり糖原合成もまた進しているものと推測される。一 
方 alloxan 糖尿病動物を同じ食餌で飼育すると肝 phosphorylase 活性上昇は認められない. とのととから 高糖質食は膵ラ氏島 $\beta$ 細胞の健全な状態で肝 phosphorylase 活性上昇に健くものと考光られる。．さらに正 常動物でみられた筋糖原量の増加は alloxan 糖尿病動物ではみられず，てれもまた insulin の関与が考え られる，すなわち正常動物に高糖質食を投与すると insulin の過分泌を起し肝，筋での糖系合成を促進す ると推測される.

\section{（III） 高脂肪食飼育の影響}

一般に高脂肪食飼育の場合は血中脂質の増加 ${ }^{4}$ がみられ，エネルギー源として糖質，糖原系への依存度が 減少するものと考えられる ${ }^{9}$. 高脂肪食飼育の本酵素への影響であるが，Table 3 亿示す加く，正常動物で は朋糖原は減少し, phosphorylase 活性は上昇し糖原分解の促進が考えられる。筋では逆に phosphorglase 活性の低下を示した。 alloxan 糖尿病動物を同じ食餌で飼育すると，肝の phosphorylase 活性の著明な低 下がみられた，正常動物にみられた phosphorylase 活性の上界が alloxan 糖尿病動物でみられないという 著者の成績は insulin の関与を考えさせる.

(IV) 肝, 筋 phosphorylase 活性変動様式について

著者は前報1 において phosphorylase 活性の直接支配ホルモンの作用の相違点に注目し，肝，筋ともに 本酥素活性上昇する場合を epinephrine 型変動, 肝でのみ活性上昇をみる場合を glucagon 型変動と仮称 して $2 \sim 3$ のホルモン投与の成績を検討した。本研究の結果について同様の見方を試みると，絶食，高糖質 食飼育, 高脂肪食飼育でいずれの場合も glucagon 型を示している. 絶食時のホルモン環境の変化について は Unger R.H., ${ }^{10}$ 等は飢餓72時間で未梢静脈血中の glucagon は約 3 倍に増加したと報告している. 絶食時

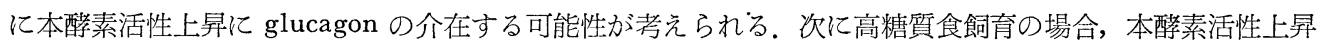
は既述のように insulin の関与を必要とするようである。 insulin と phosphorylase 活性上昇との関係に ついては前報において，相当大量の外来性 insulin 投与の場合は肝，筋ともに本䣼素活性上昇をみとめ epinephrine 型であるのに cortisol 投与では内因性 insulin の過分泌が考えられ(1)，肝でのみ活性上昇し glucagon 型の動きであるてとを述べて来た．本実験の高糖質飼育による場合も同しくく insulin の過分泌が 考えられ, 上述の加く glucagon 型の変動とみなされる. てのような見方にはホルモンの定量の裏付けが必 要であるが 1 つの可能性として glucagon の関与が考学られた。

\section{総括並びに結語}

ラットにおける肝, 筋 phosphorylase 活性, 糖原量を絶食, 高糖質食, 高脂肪食飼育の条件下に検索し 次の結果を得た。

1）絶食による肝糖原量は12時間までに著減し，肝 phosphurylase 活性は 6 時間 12時間と上昇し，その 後下降した。筋 phosphorylase 活性, 筋糖原量はともに48時間, 72時間と低下の態度を示した。

2）高糖質食飼育により正常動物では, 肝phosphorylase 活性の上昇, 筋糖原量は上昇を示し, alloxan 糖尿病動物では正常動物でみられた変化は認められなかつた。

3）高脂肪食飼育により正常動では肝糖原量の減少, 肝 phosphorylase 活性の上昇, 筋 phosphorylase 活性の低下がみられ, alloxan 糖原病動物では肝 phosphorylase 活性が著明に低下した.

以上の結果から各食慨条件による糖原系の動きについて考察を加え phosphorylase 活性の変動に与えるホ ルモンの関係について論じた。

本論文の要旨は一部第 14 回日本内分泌学会西日本地方会(昭和 41 年), 第 41 回日本内分泌学会総会（昭和 43 年）京都にて発表した。

稿を終るにあたり，恩師早瀬正二教授ので稿閲ならびに種々で助言を賜わつた木島滋二前教授に深謝し， 本研究に終始で指導をいただいた京都大学老年医学講座竹内三郎助教授に深謝します。また研究に際しての 法医学教室須山弘文前教授ので援助にあっくお礼申し上げます。 
献

1）伊東 毅：日内分誌. $45 ， 2 ， 229 ，(1969)$.

2) DOROTHY, F., E.A. NIEDLE. : Metabolism, $8: 762$, (1959).

3) NIEMEYeR, H., N. PÉKes, J. RODOJKOVIC, T. URETA. : Arch Bioch. Biophysics, $96: 662$, (1962). 4) 山田弘三: 糖尿病, $9: 112,(1966)$.

5) LANGDON, R.G., D.R. WEUKLEY. : J. Biol. Chem., 214 : 167, (1955).

6) WEBER, G., A. CANTERO. : Science, $120: 851$, (1954). $\quad$ 7) WILLMER, J.S. : Candian, J. Biochem. physiol., $38: 1095$, (1960). 8) NIEMEYER, H., C. GONZALEZ, R. ROZZI, J. Biol. Chem., $236: 610,(1961) . \quad 9$ ) DAVID, R.H., P.H., JOHN, V.N. LUGIL : Am. J. Phy. $199: 1041$, (1960). 10) UNGER, R.H., A.M. EISENTRANT : Diabetes $13: 563$, (1964). 